\title{
CHARACTERIZATION OF ROMANIAN AGRICULTURAL HOLDINGS
}

\author{
TAbita Adamov, Tiberiu IANCU, IOAN BRAd, ANDrea FeHÉR
}

\author{
Banat's University of Agricultural Sciences and Veterinary Medicine fromTimisoara \\ Faculty of Farm Management \\ Calea Aradului, no.119, 300645, Timisoara, Romania \\ tabitaadamov2003@yahoo.com
}

\begin{abstract}
Agricultural holding constitute it self as a form of organization, existent and in operation of the production process from agriculture. Organization and operation of agricultural holdings can be realized under various forms, from the easiest way - family farms, to private companies, family businesses and even private agricultural societies in case of companies with state capital (public etc.). The changes that occurred in Romania postdecembrieste agriculture are based on Law $18 / 1991$, law which determined mainly changes regarding the land ownership, meaning its transfer into private ownership and acquisition by the former owners of property rights on earth. Application of land reform from 1991 and re allotment of Romanian peasants has as effect the increased fragmentation of agricultural land. So, the existence and functioning of a land market involves, primarily, the establishment of some farms profitable, of larger size, with a high degree of profitability and witch to allow all at once obtaining some competitive agricultural products with those of European countries.
\end{abstract}

Keywords: agricultural land, farms, subsistence farms, commercial farms

\section{INTRODUCTION}

Efficient use, from economic point of view of the main source of production, the land found, constitutes in a market economy, the base of a functional land market, which, allows landowners to organize themselves in performant farms and their optimum sizing. In the process of economic development of EU member states with medium incomes, the main adjustments brought to the agricultural sector aimed, in particular, the investments in small farms modernization, less competitive and development of these, in order to transform them into commercial farms, which to allow increasing of incomes for farmers.

\section{MATERIAL AND METHOD}

In order to realize this study we used, besides specialized literature and data's provided by the Ministry of Agriculture, the Statistical Yearbooks of I.N.S and Structural Survey in Agriculture and also the data's provided by European Yearbooks (Eurostat). Scientific research methods used were: the binom induction and deduction and comparative analysis, used in comparing specific indicators of agricultural holdings, in different periods of time or in the same time period in Romania and the EU.

\section{RESULTS}

Romania has large areas of arable land with good quality soils. Natural conditions and environment gives to Romania great possibilities for development of a sustainable and performant agriculture, however, land fragmentation due to changing of ownership forms, lack of investments in farms modernization and backwardness regarding the agricultural policies do not allow efficient use of production resources and, mainly, of the land resources. (BRAD, 2015) 
The application of the Land Law no. 18 of 1991 has made as private propriety on agricultural land to be dominant. The analysis by type of ownership of agricultural land shows that the most part of the lands are in private, individual or public propriety. So, until now, $95 \%$ from the agricultural land is in privat propriety. (IANCU, 2007)

The main types of farms that have constituted after the application of the land laws are: individual farms, family associations, agricultural companies, commercial agricultural companies. (FEHER, 2009)

Individual farms, agricultural companies with legal personality and family associations form the private sector of agriculture. Together they use $95 \%$ from the agricultural surface of the country. The most part of the utilized agricultural area is exploited in individual households $(65.2 \%)$ and large units with legal personality exploits $34.8 \%$ from UAS.

After implementation the Land Law, Romania has faced and still faces with a high degree of fragmentation of agricultural land. (Table 1.)

Table 1. The situation of agricultural holdings

\begin{tabular}{|c|c|c|c|c|c|c|c|c|c|}
\hline \multirow[t]{2}{*}{ Indicators } & \multicolumn{3}{|c|}{ Holdings - total } & \multicolumn{3}{|c|}{$\begin{array}{l}\text { Agricultutal hodings } \\
\text { without legal status }\end{array}$} & \multicolumn{3}{|c|}{$\begin{array}{l}\text { Agricultutal hodings } \\
\text { with legal status }\end{array}$} \\
\hline & 2002 & 2010 & 2013 & 2002 & 2010 & 2013 & 2002 & 2010 & 2013 \\
\hline $\begin{array}{l}\begin{array}{l}\text { Numer of holdings } \\
\text { (thousands) }\end{array} \\
\end{array}$ & 4485 & 3859 & 3630 & 4462 & 3828 & 3602 & 23 & 31 & 28 \\
\hline $\begin{array}{l}\text { Agricultural area in use } \\
\text { (thousands ha) }\end{array}$ & 13931 & 13306 & 13056 & 7709 & 7450 & 7271 & 6222 & 5856 & 5785 \\
\hline $\begin{array}{l}\text { - arable (thousands } \\
\text { hectares) }\end{array}$ & 8774 & 8306 & 8198 & 5437 & 4725 & 4558 & 3337 & 3581 & 3640 \\
\hline $\begin{array}{l}\text { - pastures and hayfields } \\
\text { (thousands ha) }\end{array}$ & 4644 & 4506 & 4398 & 1878 & 2307 & 2315 & 2766 & 2199 & 2083 \\
\hline $\begin{array}{l}\text { permanent crops } \\
\text { (thousands ha) }\end{array}$ & 344 & 312 & 302 & 225 & 236 & 240 & 119 & 76 & 62 \\
\hline - gardens (thousands ha) & 169 & 182 & 158 & 169 & 182 & 158 & - & - & \\
\hline $\begin{array}{l}\text { Average agricultural } \\
\text { area in use (ha) }\end{array}$ & 3.11 & 3.45 & 3.60 & 1.73 & 1.95 & 2.02 & 274.43 & 190.78 & 207.49 \\
\hline
\end{tabular}

Source: INS

The analysis of agricultural holdings by legal status highlights a high percentage of the farms, without legal personality (individual households).

In the period 2002-2013, at national level it may be seen a reduction of the number of agricultural holdings (-19.06\%), the main cause being the merging of lands and increasing the average size by farm, from $3.11 \mathrm{ha} / \mathrm{holding}$ in the year 2002 , to $3.45 \mathrm{ha} /$ holding in the year 2011 and 3.6 ha/holding in the year 2013.

Agricultural holdings, without legal personality, $99.23 \%$ from the total number of existing agricultural holdings at national level, in the year 2013, exploit the largest agricultural area, $55.69 \%$, with an average of $2.02 \mathrm{ha} /$ holding. Compared to the year 2002 , the number of such type of agricultural holdings was reduced with $19.27 \%$. Regarding the total agricultural area, used, it was decreased with 438,000 ha, while the average size of holdings increased from $1.73 \mathrm{ha} /$ holding to $2.02 \mathrm{ha} /$ holding.

So, from the 3,602 thousand individual agricultural holdings witch have a utilized agricultural area of 7.27 million ha, $89.9 \%$ have a surface less than 5 ha, the production obtained being entirely destined for own consumption. Over $98 \%$ from these are mixed holdings both for crop production and livestock, a classification of them by area or by the number of animals being not conclusive.

In Romanian agriculture, agricultural holdings with legal personality, hold a very small share, $0.77 \%$, exploiting an area of 5.785 million ha $(44.31 \%)$ from useful agricultural surface at national level. Even if these types of holdings are found in small number, the 
average size of such holding is very high compared to the ones without legal personality 207.49 ha/holding, in the year 2013. Although during the period 2002-2013 there has been a decrease of the average size of agricultural holdings with legal personality, compared to the year 2010, it can be seen an increase of this indicator.

It notices the small share of associative forms of only $7.02 \%$ from the total utilized agricultural area, such as the lack of associative forms for marketing agricultural products, such as producer groups or agricultural cooperatives.

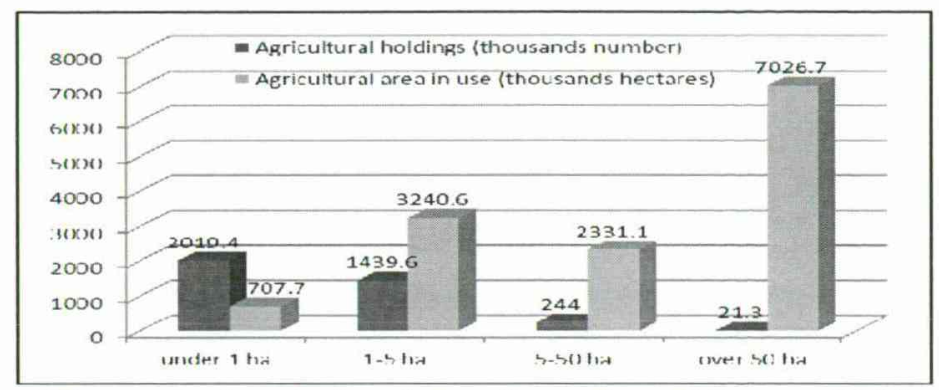

Figure 1. Analysis of the class size of farms, 2010

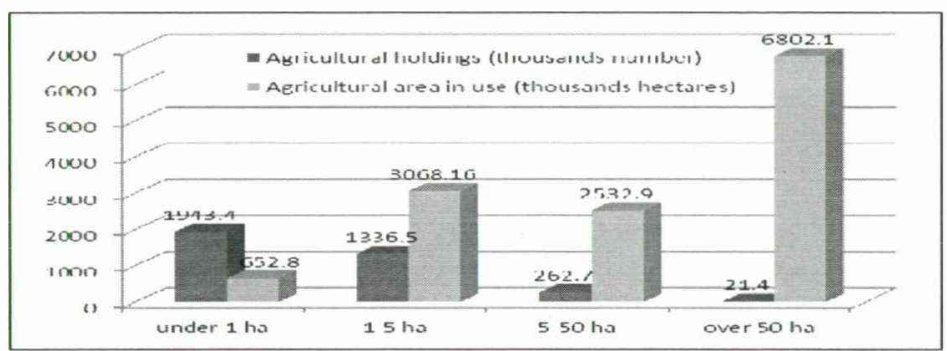

Figure 2. Analysis of the class size of farms, 2013

The analysis by class sizes of agricultural holdings, comparative in the year 2010 (Figure 1) and 2013 (Figure 2) highlights the following aspects: (BRAD ET ALL., 2015)

- agricultural holdings less than 1 ha, decreased from 2.019 million holdings, in 2010 to 1.9434 million holdings in 2013;

- agricultural holdings of size class 1-5 ha, in the year 2010, have also experienced a decrease, of $7.16 \%$ from 1.439 million holdings, to 1.336 million holdings in 2013;

- agricultural holdings from the category under 1 ha and those from 1-5 ha size category, exploits together in the year 2010, 3.948 million hectares, meaning $29.67 \%$ from the total of useful agricultural area (USA), while in the year 2013, operates a smaller area, 3.694 million hectares, meaning $28.5 \%$;

- the other two size classes 5-50 and over 50 ha, represents in the year $2010,7.12 \%$ and exploit together, 9.358 million ha $(70.32 \%)$ while at the level of the year 2013 represents $7.97 \%$ and exploits $71.5 \%$ from useful agricultural area.

Comparing the situation of agricultural holdings from Romania with the one from EU, during the period 2002-2013, it can be drawn the following conclusions: (STANCIU, 2013)

- Romania holds the largest number of agricultural holdings from EU (3.63 million agricultural holdings);

- $28.69 \%$ from total number of agricultural holdings existent at the level of EU can be found in our country;

- The average size of an agricultural holding in Romania is in the year 2013, much lower (3.60 ha) compared to the EU average (11.7 ha);

- The average size of an agricultural holding in Romania, from the year 2002 in the year 2010 has increased slightly, from 3.11 to 3.60 ha; 
Defining the small farms as having a surface of 5 ha, they represented, in $2013,92.3 \%$ from total of Romanian agricultural holdings and worked $23.55 \%$ from the utilized agricultural area (subsistence farms with dimensions less than two hectares representing $71 \%$ from total holdings and operating $13 \%$ from utilized agricultural area, from which holdings under one hectare occupied $5.0 \%$ from utilized agricultural area).

Table 2. The share of small farms (after the criteria and thresholds most used) in the total number of agricultural holdings in 2007, EU (\%)

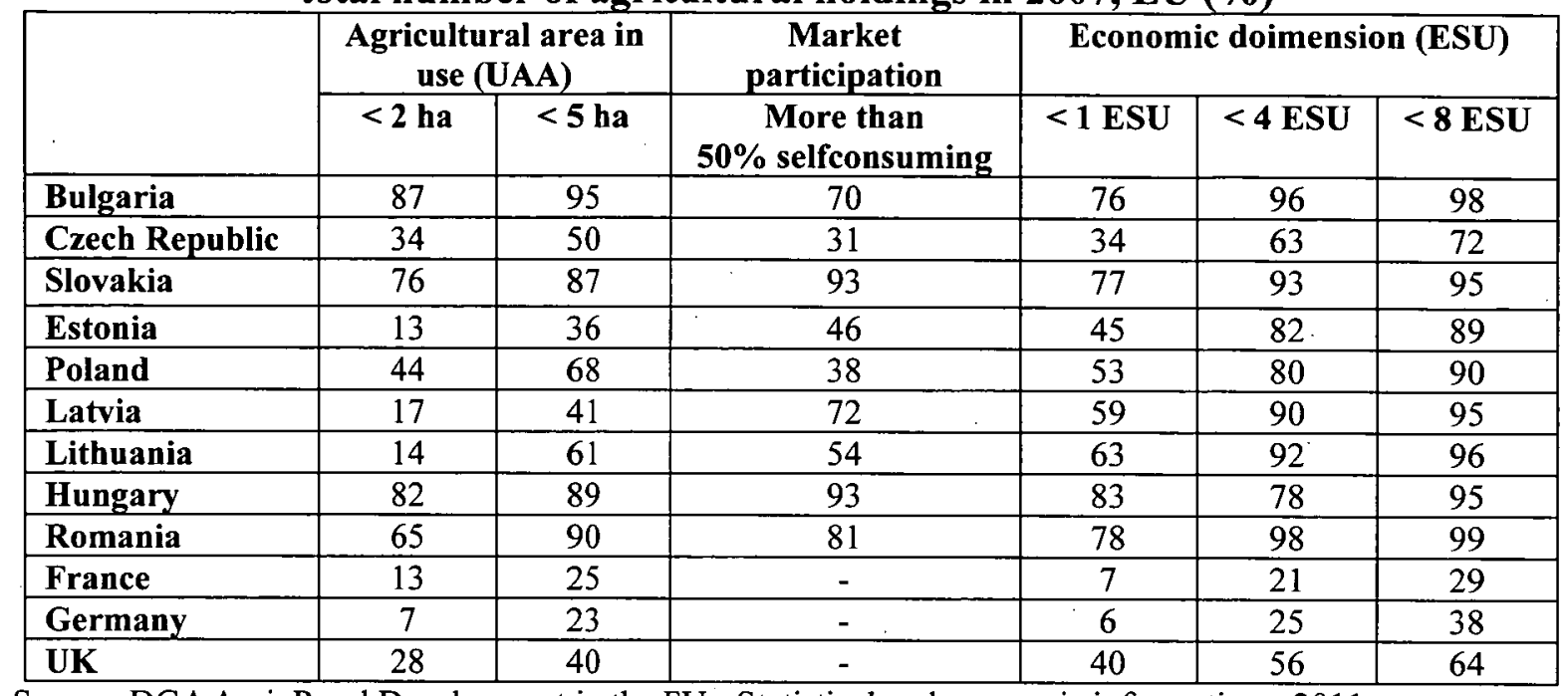

Source: DGA Agri, Rural Development in the EU - Statistical and economic information - 2011

Considering the economic limit 8 ESU in order to define all small farms (subsistence and semi-subsistence), these comprise $99 \%$ from agricultural holdings of Romania, $98 \%$ from those from Bulgaria, $96 \%$ from those of Lithuania, respectively $95 \%$ from those of Latvia and Hungary (Table 2).

Such a distribution accentuated bipolar, with most part of agricultural land divided, on the one hand, between holdings extremely modest in physical and economic size, which produce mainly for own needs, do not invest and do not generate consume on the market, and on the other hand, a relatively small number of farms that produce in industrial system and adopt modern technologies, constitutes the main factor witch limits the increasing of the competitiveness of Romanian agriculture. The duality of Romanian agricultural sector is one of the greatest challenges of policy makers, maintaining despite of some measures meant to lead to lands consolidation and inter-sectorial reallocation of labor force.

The classification of Romanian farm having on base the economic size, may constitute as base, witch to allow the adaptation of Romanian agriculture to European Union requirements in the period 2014-2020, thus creating premises for taking decisions regarding the programming and using the Community funds.

The accession to the European Union has brought profound changes regarding the orientation of rural development and agriculture, by the principles of the Common Agricultural Policy (CAP), having as main objective, increasing the productivity, the development of rural areas by improving the living standards, ensuring the quality of food products and food security, the competitiveness of agricultural and food markets and prices stability.

Since the moment of accession, through its programs of support of the agriculture, the European Union has tried to encourage the attraction of funds for development and modernization of Romanian agriculture in general and of the agricultural holdings in particular. 
The strategy of European Union 2020 regarding rural development aims that, fin the futurethe economic growth to be based on knowledge and innovation, sustainable and inclusive. So, for the period 2014-2020 EU rural development policy follows three main objectives: the competitiveness of agriculture; sustainable management of natural resources; balanced territorial development of rural areas. (RAICOV ET ALL., 2013)

In present, in Romania, through the Rural Development Programm its try reducing the existing gap at national level, concerning agricultural holdings. So, funding programs aim specifically: agricultural holdings of small and medium size, and those with disfavoring conditions, encourage and support of the young farmers, creating of the new medium-sized holdings, organization of small farmers in the marketing structures of production, etc. The fact that the great latifundias own lands in lease and concession, and thus the ownership over the land is maintained by the rural population, can be a base to improve the situation.

(GHERMAN ET ALL., 2013)

The merge of agricultural lands remains a priority in the action of the development of agriculture and modernization of agricultural holdings. Next, Figure no. 3, we present the structure of agricultural holdings, by size classes, eligible SAPS, in the year 2013. (IANCU, 2013)

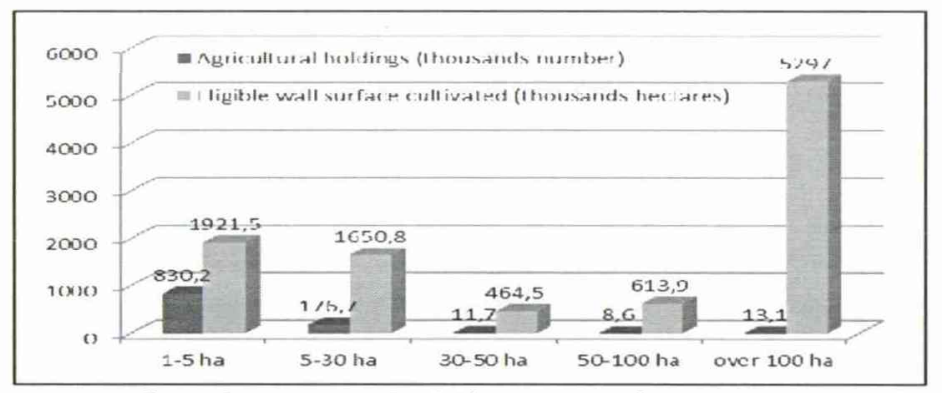

Figure 3. Structure of agricultural holdings, by size classes, eligible SAPS, 2013

According to data's from the Agency for Payments and Intervention in Agriculture (APIA), in the year 2013, are eligible a number of 1.040 million farms, but only $29.19 \%$ from the total of holdings existent at national level. Agricultural area eligible for SAPS funding is 9.948 million hectares, $76.19 \%$ from the utilized agricultural area in this year. The average of size per holding in APIA subsidizing is 9.56 ha/holding. (FEHER ET ALL., 2013)

The presence, still, in large number of small farms, in parallel with large farms, indicates a very pronounced structural imbalance that affects Romanian agriculture and its competitiveness.

\section{CONCLUSIONS}

The current state of Romanian agricultural holdings, the presence in large number of small holdings, does not allow the practice of modern agriculture and achieving of high productions, competitive on domestic and European market and at the same time the ensurance of some decent incomes for farmers. In this respect, it imposes the conversion of small holdings, mainly of peasant households in family farms with commercial character, modern, which can effectively use the production resources (natural, human and technological) existent or, who can be attracted through agricultural support programs offered by the European Union.

Achieving these goals requires actions and measures of agricultural policy interrelated between them and sustainable in time: 
- encouraging and supporting the increasing of dimension and economic size of agricultural holdings;

- stimulation of farmers in attracting European funds for the development of farms as weil as for strengthening their own financing sources;

- development of associative and cooperation forms in order to increase the concentration degree of agricultural production and of the possibilities of it capitalization;

- increasing the productivity of labor and of the incomes of farmers;

- a better information on the future agricultural policy, mainly on the posibilities to support small-scale farms;

- encouraging farmers to invest in private infrastructure projects: storage, cooling, packing, etc., and development of some processing activities of the products obtained, of the development of short chains interposed between producers and consumers, thereby facilitating the instalation of young farmers, creating new jobs and encouraging younger generations to get involved in agriculture sector;

- stimulation of employment in rural area and of the entrepreneurship spirit;

\section{ACKNOWLEDGEMENTS}

This work was supported by grant of the Romanian National Authority for Scientific Research and Innovation, CNCS-UEFISCDI, project number PN-II-RU-TE-2014-4-1134.

\section{REFERENCES}

BRAD I. (2015): Managementul producţiei, Eurostampa, Timişoara

Brad I., Gherman R., Mănescu Camelia Sirbulescu Claudia, Dincu Ana-Mariana (2015): Study regarding the current situation of farms in Romania, Journal of Biotechnology (ISSN: 0168-1656) 208S: S63.

IANCU T. (2013): Agricultural cooperative, fundamental condition for Romanian agricultural development, Lucrări ştiinţifice Management Agricol 14(2)

FEHER ANDREA (2009): Finanțarea agriculturii și dezvoltării rurale - Politici agricole, Editura Orizonturi universitare, Timișoara

Feher Andrea, Hurmuzache Tabita Cornelia, Toader Cosmina Simona (2013): Financial support of Romanian rural area in the context of the post-2013 budgetary perspective, AgroBuletin AGIR, nr. 16

GHERMAN R. Dincu ANA-MARIANA, BRAD I., IANCU T. (2013): Agricultural cooperative, fundamental condition for Romanian agricultural development, Lucrări ştiinţifice Management Agricol, vol. XIV(2)

IANCU T. (2007): Economie agrară, Editura Agroprint, Timișoara

DGA AGRI (201): Rural Development in the EU - Statistical and economic information INSTITUTUl NAȚIONAL DE STATISTICĂ (2015): Anularul Statistic al României

InSTITUTUl NAȚIONAL DE STATISTICĂ (2014): Ancheta Structurală în Agricultură 2013 rezultate finale

Raicov M., GoŞa V., Feher Andrea, Hurmuzache Tabita, GoŞa C. (2013): Rural development policy of the European Union between 2014 and 2020, Lucrări ştiinţifice Management Agricol 15(3)

STANCIU S. (2013): Research on legal measures applied under the common Agricultural Policy of European union in 2012, Lucrări Ştiinţice Management Agricol 15(3) 